8. Державне управління: європейські стандарти, досвід та адміністративне право / В. Б. Авер'янов, В.А. Дерець, А. М. Школик та ін.; за заг. ред. В. Б. Авер'янова. Київ: Юстініан, 2007. 288 с.

9. Про внесення змін до деяких законодавчих актів України щодо удосконалення порядку надання адміністративних послуг у сфері будівництва та створення Єдиної державної електронної системи у сфері будівництва: Закон України від 17.10.2019 № 199-IX. URL: https://zakon.rada.gov.ua/laws/show/199-20\#Text.

10. Про ліквідацію Державної архітектурно-будівельної інспекції та внесення змін до деяких постанов Кабінету Міністрів України: Постанова Кабінету Міністрів України від 13.03.2020 № 218. URL: https://zakon.rada.gov.ua/laws/show/218-2020-\%D0\%BF\#Text.

11. Васильєва Н. В. Сервісна держава: різноманітність розуміння та проблемність побудови. Університетські наукові записки. 2017. № 1. С. 279-288. URL: http://nbuv.gov.ua/UJRN/Unzap_2017_1_30.

\title{
REFERENCES:
}

1. Liashko, O. B. (2014). Providing administrative services in the field of urban planning: the results of sociological research. Chasopys Kyivskoho universytetu prava, 4, 117-121. Retrieved from: http://nbuv.gov.ua/UJRN/Chkup_2014_4_28 [in Ukrainian].

2. Law of Ukraine On the basics of urban planning № 2780-XII. (1992, November 16). Retrieved from: https://zakon.rada.gov.ua/laws/show/2780-12\#Text [in Ukrainian].

3. Huk, B. (2011). Administrative services of public authorities of Ukraine: concept, content. Pravo $i$ suspilstvo, 3, 117-121. Retrieved from: http://nbuv.gov.ua/UJRN/Pis_2011_3_25 [in Ukrainian].

4. Averianov, V. (2011). Selected scientific works. Shemshuchenka, Yu., \& Andriiko, O. (Eds.). Kyiv: In-t derzhavy i prava im. V.M. Koretskoho NAN Ukrainy [in Ukrainian].

5. Law of Ukraine On administrative services № 5203-VI. (2012, September 6).. Retrieved from: https://zakon.rada.gov.ua/laws/show/5203-17\#Text [in Ukrainian].

6. Stetsenko, S. H. (2007). Administrative law of Ukraine: Textbook. K.: Atika [in Ukrainian].

7. Bondarenko, A. (2018). The essence of the public service state in the mechanism of protection of human and civil rights and freedoms. Jurnalul juridicnational: teorieşipractică, 2, 9-12. Retrieved from: http://jurnaluljuridic.in.ua/archive/2018/2/part_2/2.pdf [in Ukrainian].

8. Averianov, V. B. (Ed.). (2007). Public administration: European standards, experience and administrative law. Kyiv: Yustinian [in Ukrainian].

9. Law of Ukraine On amendments to some legislative acts of Ukraine to improve the procedure for providing administrative services in the field of construction and the creation of a Unified State Electronic System in the field of construction № 199-IX. (2019, October 17). Retrieved from: https://zakon.rada.gov.ua/laws/show/19920\#Text [in Ukrainian].

10. On liquidation of the State Architectural and Construction Inspectorate and amendments to some resolutions of the Cabinet of Ministers of Ukraine. (2020). Resolution of the Cabinet of Ministers of Ukraine 13.03.2020 № 218. Retrieved from: https://zakon.rada.gov.ua/laws/show/218-2020-\%D0\%BF\#Text [in Ukrainian].

11. Vasylieva, N. V. (2017). Service state: diversity of understanding and problems of construction. Universytetski naukovi zapysky, 1, 279-288. Retrieved from: http://nbuv.gov.ua/UJRN/Unzap_2017_1_30 [in Ukrainian].

Стаття надійшла до редакції: 10.06.2020

\author{
УДК 338.48 \\ DOI: $10.36550 / 2522-9230-2020-1-9-141-144$
}

ПОНЯТТЯ СОЦІАЛЬНО-ЕКОНОМІЧНОГО РОЗВИТКУ В РЕГІОНІ

\author{
Пузаков Дмитро Володимирович, \\ викладач кафедри \\ державно-правових дисииплін та адміністративного права \\ Центральноукраӥнського державного педагогічного \\ університету імені Володимира Винниченка \\ e-mail: dvpuzakov@ukr.net \\ https://orcid.org/0000-0002-9550-4185
}

\footnotetext{
У статті звертається увага, що з початком проведення ринкових реформ відмінності в соціально-економічному розвитку регіонів стали збільшуватися, що пояснюється відмінностями в структурі економіки кожного регіону, що супроводжуються значним ослабленням регулюючої ролі держави. Мета статті - визначити сутність поняття соціальноекономічного розвитку та встановити відмінність із суміжними категоріями «розвитку», «регіонального розвитку», «сталого розвитку регіону». Встановлено, що регіональний розвиток $є$ процесом або особливим режимом
} 
функціонування регіону, орієнтованим на позитивну динаміку всіх основних параметрів рівня життя, яка забезпечена стійким і збалансованим відтворенням господарського потенціалу, ресурсного, економічного, соціально демографічного потенціалу. Серед факторів, що впливають на процес якісного регіонального розвитку виокремлено демографічні, природно-ресурсні, соціально-економічні, екологічні, а також історичні, політико-правові, організаційні, технологічні, кадрові тощо. Соціально-економічний розвиток регіонів розглядається як комплексний процес змін в економіці i соціальній сфері муніципалітету, націлений на поліпшення якості життя населення даної території. У статті акцентовано, що соціально-економічний розвиток включає такі основні компоненти: зростання виробництва і доходів; зміни в інституційній соціальній і адміністративній структурах суспільства; зміни в суспільній свідомості; зміни в традиціях і звичках. У свою чергу, сталий соціально-економічний розвиток означає реалізацію трьох взаємопов'язаних і взаємообумовлених цілей: створення більш конкурентоспроможною, високоефективної і низьковитратної економіки; підвищення життєвого рівня населення; поліпшення екологічної обстановки.

Ключові слова: регіон, регіональний розвиток, соціально-економічний розвиток, територія, сталий соціальноекономічний розвиток.

\section{Puzakov D. THE CONCEPT OF SOCIO-ECONOMIC DEVELOPMENT IN THE REGION}

The article draws attention to the fact that with the beginning of market reforms, differences in the socio-economic development of regions began to increase, due to differences in the structure of the economy of each region, accompanied by a significant weakening of the regulatory role of the state. The purpose of the article is to define the essence of the concept of socio-economic development and to establish a difference with the adjacent categories of "development", "regional development", "sustainable development of the region". It is established that regional development is a process or special mode of functioning of the region, focused on the positive dynamics of all major parameters of living standards, which is provided by sustainable and balanced reproduction of economic potential, resource, economic, socio-demographic potential. Among the factors influencing the process of qualitative regional development are demographic, natural resources, socio-economic, environmental, as well as historical, political and legal, organizational, technological, personnel, etc. Socio-economic development of the regions is seen as a comprehensive process of change in the economy and social sphere of the municipality, aimed at improving the quality of life of the population of the area. The article emphasizes that socio-economic development includes the following main components: growth of production and income; changes in the institutional social and administrative structures of society; changes in public consciousness; changes in traditions and habits. In turn, sustainable socio-economic development means the realization of three interrelated and interdependent goals: the creation of a more competitive, highly efficient and low-cost economy; raising the living standards of the population; improving the environmental situation

Key words: region, regional development, socio-economic development, territory, sustainable socio-economic development.

Постановка проблеми. Історично сформовані відмінності в соціально-економічному розвитку регіонів України мають неабиякий вплив на структуру та ефективність економіки країни в цілому, стратегію інституціональних перетворень і соціально-економічної політики. 3 початком проведення ринкових реформ відмінності в соціально-економічному розвитку регіонів стали збільшуватися, що можна пояснити відмінностями в структурі економіки кожного регіону, що супроводжуються значним ослабленням регулюючої ролі держави. Диференціація регіонів за рівнем життя, доступності соціальних послуг, розвитку виробничої та транспортної інфраструктури особливо загострилася в період фінансової кризи. Питання державним управління соціально-економічним розвитком стали особливо актуальними. Однак, насамперед, необхідно визначити, що ж включає в себе «соціально-економічний розвиток регіону» та прослідкувати кореляцію цього поняття із суміжними категоріями «розвитку», «регіонального розвитку», «сталого розвитку регіону».

Аналіз останніх досліджень та публікацій. Проблематиці дослідження питання соціальноекономічного розвитку регіону та менеджменту цим процесом присвячені фундаментальні праці українських вчених, серед яких найбільшою грунтовністю відрізняються наукові доробки О.М. Алимова, O.I. Амоші, C.I. Бандура, М.П. Бутка, В.М. Геєця, Б.М. Данилишина, Л.В.Дейнеко, М.I. Долішного, С.І.Дорогунцова, Ф.М.Заставного, Б.А. Гаєвського, Т.А. Заяць, О.А. Єпіфанова, В.І. Куценко, В.С.Коломійцева, В.І. Кравченка, В.Г. Кременя, Ю.П. Лебединського, А.С.Лисецького, О.М. Паламарчука, B.I. Пили, М.I. Чумаченка, Л.Г. Чернюк, М.І. Фащевського та ін.

Мета статті - визначити сутність поняття соціально-економічного розвитку та встановити відмінність із суміжними категоріями «розвитку», «регіонального розвитку», «сталого розвитку регіону».

Виклад основного матеріалу дослідження. Слово «розвиток» українські філологи пов'язують із процесом, унаслідок якого відбувається зміна якості чого-небудь, перехід від одного якісного стану до іншого, вищого [1]. Сьогодні «розвиток» часто вживається в різних поєднаннях: економічний розвиток, соціально-економічний розвиток, розвиток регіону тощо. У будь-якому випадку під розвитком розуміється будь-прогресивна зміна в економічній сфері. Якщо зміна кількісна, то розуміється економічне зростання, якщо якісна - мова йде про структурні зміни, а якщо комплексна, то мається на увазі цілісний розвиток регіону.

У цілому, розвиток регіону - багатоаспектний процес, що зазвичай розглядається 3 точки зору сукупності різних соціальних і економічних цілей $[2,20]$. Регіональний розвиток можна визначити на основі дослідження змін окремих параметрів, що характеризують регіон з різних ракурсів [7].

В. А. Велкова наголошує на тому, що регіональний розвиток є режимом функціонування регіону, орієнтованим на позитивну динаміку всіх основних параметрів рівня життя, яка забезпечена стійким i 
НАУКОВІ ЗАПИСКИ. СЕРІЯ: ПРАВО | SCIENTIFIC NOTES. SERIES: LAW

\section{збалансованим відтворенням господарського потенціалу, ресурсного, економічного, соціально} демографічного потенціалу [3].

Е. Дж. Блейклі визначає регіональний розвиток як процес, в якому місцева влада або організації залучаються до стимулювання або підтримки ділової активності та/або соціальної зайнятості в регіоні. Головна мета регіонального економічного розвитку полягає в тому, щоб стимулювати можливості працевлаштування в галузях і секторах економіки, які покращують якість життя громади, використовуючи існуючі людські, природні та інституційні ресурси[12].

Якщо звернутись до нормативно-правової бази у сфері регіонального розвитку України, а саме до інституційного закону України «Про засади державної регіональної політики» № 156-VIII від 05.02.2015, можемо знайти наступне визначення: регіональний розвиток - процес соціальних, економічних, екологічних, гуманітарних та інших позитивних змін у регіонах [10].

Серед факторів, що впливають на процес якісного регіонального розвитку В.Г.Ковальчук виокремлює демографічні, природно-ресурсні, соціально-економічні, екологічні, а також історичні, політико-правові, організаційні, технологічні, кадрові тощо [6]. Відповідно до цієї тези, розуміємо, що соціально-економічний розвиток є більш вузьким поняттям порівняно із узагальнюючою категорією регіонального розвитку.

Так, В. Н. Іванова, соціально-економічний розвиток регіонів розглядає як комплексний процес змін в економіці і соціальній сфері муніципалітету, націлений на поліпшення якості життя населення даної території [5, с.271].

Деталізує попереднє визначення $€$. Зарова, яка у соціально-економічному розвитку регіону вбачає процес безперервного економічного зростання території регіону, що відбувається під впливом зовнішніх $\mathrm{i}$ внутрішніх виробничих, інституційних, соціальних факторів, та забезпечує підвищення рівня і якості життя його населення [4, с. 213].

П.В.Мельник стверджує, що соціально-економічний розвиток включає такі основні компоненти: зростання виробництва i доходів; зміни в інституційній соціальній i адміністративній структурах суспільства; зміни в суспільній свідомості; зміни в традиціях і звичках [8, с. 124].

Тож, підкреслимо, що соціально-економічний розвиток у широкому сенсі $є$ процесом підвищення рівня життя населення. Насамперед, це збільшення кількості та якості громадських і приватних благ (товарів, робіт, послуг), що надаються населенню, в тому числі і отриманих при взаємовигідному обміні 3 іншими територіями.

Крім того, зауважимо, соціально-економічний розвиток може бути пов’язаним зі збільшенням кількості і якості благ, що знаходяться в обігу території для цілей більш високих рівнів територіальної організації влади (на безоплатній основі). Наприклад, перерозподіл фінансових коштів між територіями в міжбюджетних відносинах. Тобто, соціально-економічний розвиток може припускати конфлікт між інтересами території і більш високих рівнів влади.

Що стосується учасників правових відносин, що формуються у процесі соціально-економічного розвитку, звернемо увагу, що ними можуть бути держави, їх адміністративно-територіальні одиниці, муніципалітети, комерційні і некомерційні організації та підприємства, громадські організації громадян і окремі громадяни, реалізація цілей яких веде до соціально-економічний розвиток території [11].

Часто у юридичній науці та практиці зустрічаємо суміжну категорію сталого соціально-економічного розвитку регіону. В цілому, сталий соціально-економічний розвиток території передбачає вибір такого способу розвитку, при якому досягнення його цілей в даний момент сприяє їх досягненню в майбутньому. Це раціональне та обгрунтоване використання потенціалу території, що зберігає ресурси, виробничу базу і т.д. для майбутніх поколінь.

Крім того, необхідними є заходи з розвитку та збільшення потенціалу території. При цьому, може бути конфлікт між поточним виробництвом благ і збереженням ресурсного потенціалу на майбутнє, між поточним споживанням і збільшенням економічного потенціалу території. Як зазначає Г. А. Морозова, для сталого розвитку регіону потрібно вирішити соціальні проблеми населення. Активна соціальна політика $є$ найважливішою умовою конкурентоспроможності економіки адміністративно-територіальної одиниці. При відсутності соціальних орієнтирів на ринковий механізм призведе до деградації людського потенціалу і буде гальмувати економічний розвиток в цілому [9, с. 125].

На думку А.І. Степочкина, сталий соціально-економічний розвиток означає реалізацію трьох взаємопов'язаних і взаємообумовлених цілей: створення більш конкурентоспроможною, високоефективної i низьковитратної економіки; підвищення життєвого рівня населення; поліпшення екологічної обстановки $[11$, c. 44$]$.

Висновки. Таким чином, на підставі опрацьованих доктринальних поглядів науковців, можемо зробити висновок, що соціально-економічний розвиток взаємопов'язаний з такими суміжними категоріями як регіональний розвиток, сталий регіональний розвиток. Серед факторів, що впливають на процес якісного регіонального розвитку виокремлено демографічні, природно-ресурсні, соціально-економічні, екологічні, а також історичні, політико-правові, організаційні, технологічні, кадрові тощо. Соціально-економічний розвиток включає такі основні компоненти: зростання виробництва i доходів; зміни в інституційній соціальній і адміністративній структурах суспільства; зміни в суспільній свідомості; зміни в традиціях і звичках. Суміжна категорія сталого розвитку означає реалізацію трьох взаємопов'язаних i 
взаємообумовлених цілей: створення більш конкурентоспроможною, високоефективної і низьковитратної економіки; підвищення життєвого рівня населення; поліпшення екологічної обстановки.

\section{СПИСОК ВИКОРИСТАНОЇ ЛІТЕРАТУРИ:}

1.Бусел В. Т. Великий тлумачний словник сучасної української мови. К. ; Ірпінь : Перун, 2005.

2.Буянова М.Э. Оценка региональных рисков регионов Южного федерального округа. Регионология. 2006. №3. C. 20-32.

3.Велкова В. А. Региональное развитие и управление комплексным социально-экономическим развитием дотационного региона. Вестник ЧГУ. 2009. №4. URL: https://cyberleninka.ru/article/n/regionalnoerazvitie-i-upravlenie-kompleksnym-sotsialno-ekonomicheskim-razvitiem-dotatsionnogo-regiona.

4.Зарова Е. В. Эконометрическое моделирование и прогнозирование развития региона в краткосрочном периоде: Монография. М.: Экономика, 2004. 149 с.

5.Иванова В.Н. Технологии муниципального управления: Учеб.пособие. М.: Финансы и статистика. 2005. 395 c.

6.Ковальчук В. Г. Цілі та критерії соціально-економічного регіонального розвитку. Державне будівництво. 2012. № 2. URL: http://www.kbuapa.kharkov.ua/e-book/db/2012-2/doc/2/07.pdf

7.Медвідь В. Ю. Наукові засади визначення сутності регіонального розвитку. Актуальні проблеми економіки. №7(133), 2012. С. 157-163.

8.Мельник П.В. Соціально-економічні процеси: методологія дослідження та управління їхнім розвитком. Ірпінь: Академія ДПС України, 2000. 451 с.

9.Морозова Г.А., Зимин В. А. Правовое государство: его основные признаки, черты, проблемы. Вестник Самарского муниципального института управления. 2012. № 4 (23). С. 121-128.

10. Про засади державної регіональної політики: Закон України № 156-VIII від 05.02.2015. URL: https://zakon.rada.gov.ua/laws/show/156-19\#Text

11. Тимошенко Л. М., Сімахова А. О. Соціально-економічний розвиток і його кероване забезпечення в умовах інноваційної моделі суспільної динаміки. Механізм регулювання економіки, 2015, № 1. С. 68-78. URL: https://core.ac.uk/download/pdf/141446693.pdf

12. Blakely E. J. Planning local economic development: theory and practice. Thousand Oaks, 1994. P. 15.

\section{REFERENCES:}

1.Busel, V. T. (2005). Large explanatory dictionary of the modern Ukrainian language. Irpin: Perun [in Ukrainian].

2.Buyanova, M.E. (2006). Assessment of regional risks in the regions of the Southern Federal District. Regionologiya, 3, 20-32 [in Russian].

3.Velkova V. A. (2009). Regional development and management of complex socio-economic development of a subsidized region. Vestnik $C H G U$, 4. Retrieved from: https://cyberleninka.ru/article/n/regionalnoe-razvitie-iupravlenie-kompleksnym-sotsialno-ekonomicheskim-razvitiem-dotatsionnogo-regiona [in Russian].

4.Zarova, Ye. V. (2004). Econometric modeling and forecasting of the development of the region in the short term: Monograph. Moskva: Ekonomika [in Russian]. Russian].

5.Ivanova, V.N. (2005). Municipal Management Technologies: Textbook. Moskva: Finansy i statistika [in

6.Kovalchuk, V. H. (2012). Goals and criteria of socio-economic regional development. Derzhavne budivnytstvo, 2. Retrieved from: http://www.kbuapa.kharkov.ua/e-book/db/2012-2/doc/2/07.pdf [in Ukrainian].

7.Medvid, V. Yu. (2012). Scientific principles of determining the essence of regional development. Aktualni problemy ekonomiky, 7(133), 157-163 [in Ukrainian].

8.Melnyk, P.V. (2000). Socio-economic processes: research methodology and management of their development. Irpin: Akademiia DPS Ukrainy [in Ukrainian].

9.Morozova, H.A., \& Zymyn, V. A. (2012). Rule of law: its main features, features, problems. Vestnyk Samarskoho munytsypalnoho ynstytuta upravlenyia, 4 (23), 121-128 [in Russian].

10. Law of Ukraine On the principles of state regional policy № 156-VIII. (2015, February 05). Retrieved from: https://zakon.rada.gov.ua/laws/show/156-19\#Text [in Ukrainian].

11. Tymoshenko, L. M., \& Simakhova, A. O. (2015). Socio-economic development and its managed provision in the conditions of innovative model of social dynamics. Mekhanizm rehuliuvannia ekonomiky, 1, 68-78. Retrieved from: https://core.ac.uk/download/pdf/141446693.pdf [in Ukrainian]. English].

12. Blakely, E. J. (1994). Planning local economic development: theory and practice. Thousand Oaks [in 